\title{
The supernatural in the theomachy of 2 Maccabees 9:1-29 and its role in the communicative strategy: A syntactical, semantic and pragmatic analysis
}

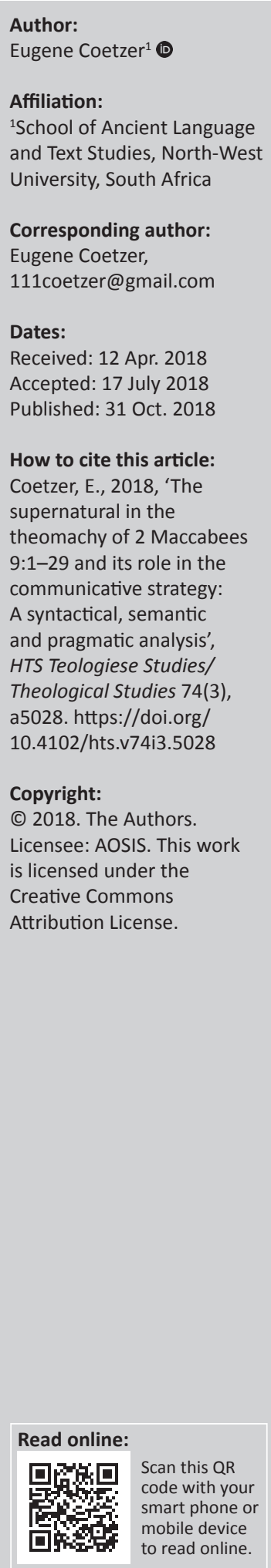

Throughout the prefixed letters and narrative of 2 Maccabees, a frequent overemphasis is discovered on certain concepts within every section or pericope. This is a logical product of such a highly rhetorical work, as this links to the overarching narrative aim of the text. These emphases subsequently lead to the question of their significance specific to this text and its subject matter. This article consequently notes, firstly, that 2 Maccabees deals with sensitive or innovative ideas and moves to drastic ways of conceptualising history in order to substantiate these ideas. It is no surprise, therefore, that in 2 Maccabees 9, one would find an overemphasis on the supernatural drive of world events to prove that the God of the Jews duly and appropriately deals with the enemies of his people. In order to explicate and unfold this process, the main ideas will be highlighted, communicative strategy investigated and the possible impact on the reader and/or hearer outlined.

\section{Introduction}

One of the most striking confrontations in the text of 2 Maccabees is that between the Syrian king Antiochus IV Epiphanes and the God of the Jews. Antiochus returns from the regions around

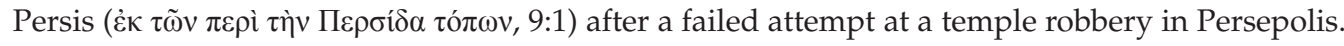
Enraged by both the last-mentioned defeat and the Jewish defeat over his men Nikanor and Timothy, he now orders his charioteer to drive on without a break to Jerusalem and sets out to

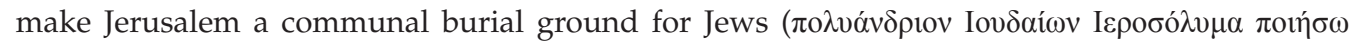

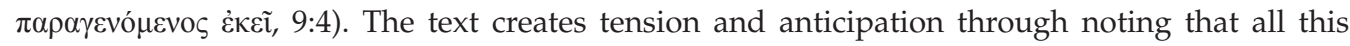

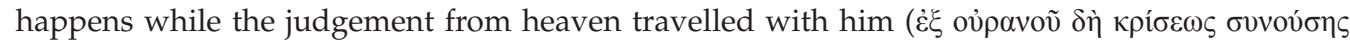

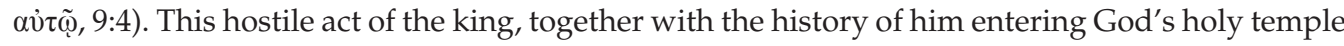
and touching the holy vessels (2 Macc. 5:15-16), now leads the reader/hearer into the official battle between God and Antiochus (2 Macc. 9:5-10), Antiochus' reaction (2 Macc. 9:11-17) and a letter from Antiochus to the Jews (18-27). In the battle, Antiochus suffers many afflictions:

- an irremediable pain seized him in his innards (9:5)

- he fell from his chariot as it rushed along (9:7)

- the limbs of his body are wrenched (9:7)

- worms swarm from his eyes (9:9)

- $\quad$ pieces of flesh crumble off him (9:9)

- his flesh starts to rot (9:9-10).

The style of this theomachy is a witness of the recognition of the rhetorical value of such an event. The text utilises the emotional value of the death of Antiochus IV Epiphanes through providing a vivid description. Here, contrary to the many other accounts of the death of the king, the text of 2 Maccabees exhibits the traditional pattern of the Divine Warrior (Doran 2012:198) where the persecutors of/perpetrators against the Jews are dealt with swiftly and directly by a holy and righteous representative, in this case God himself. This enlightens the reader of the power of the God of the Jews and the foolishness of trying to attack him.

Despite the intricacies which, together, reveal the makeup of the text's narrative aim and communicative strategy, key contributions seem to focus on approaches which deal with the clarification of ideas rather than the reason for their presence and the persuasion to adopt them. To clarify, there is a focus on philology, style, dating and pattern, but a lack of focus on the strategy persuaded the reader towards adopting certain innovative ideas. Elias Bickerman (1979:11-17), for example, searched for an intimate understanding of the parties involved. He provides a solid base for further analysis of the first two books of Maccabees. The chronology, order and detail of 
events are a priority, resulting in an investigation into historical, philological and compositional elements. In terms of focus, Jonathan Goldstein (1983:8) is not dissimilar, with the exception of discussing the text's incorporation of the Torah and the prophets. Goldstein, in the rest of his book, sets out to explain the Hellenistic and Jewish influential power play. Closer to the goals of this paper lies Robert Doran (2012:15) with his inclination towards metaphors, worldview, larger narrative units and wordplay which results in a stronger exposition of rhetorical elements. Essential to Schwartz's analysis (2008:15) is the precise demarcation of the text as a second century BCE Jewish writing, which binds the interpretation to an account of Jerusalem-centred events specifically centred round the Maccabean revolt (167-160 $\mathrm{BCE})$. The analysis thus flows from the historical setting of this document. Furthermore, Schwartz (2008:525-527) shares vital insights on composition and argues that the authors of the first prefixed letter took notice of the narrative. For Jan Willem van Henten (1997:295), the text is centred round a pattern of six key elements which unfolds to explicate the political, religious and philosophical communication. Martyrdom is the focus. And this analysis shows a text that portrays the martyrs as heroes of the Jewish people.

This variance in approach of key contributors may be summarised in Table 1 as follows.

In general, these approaches do not aim at investigating the communicative strategy. Some questions remain owing to the complex and progressive nature of a text such as 2 Maccabees - each of the questions piloting consequent, new questions:

- What are the innovative ideas?

- How does the author handle the sensitive nature of these ideas?

- How is a contract of trust achieved in order to aid in the reception and adoption of these ideas?

- What is the communicative strategy?

- What is the possible impact on the reader/hearer?

This article investigates the features of a communicative strategy in 2 Maccabees 9. It proposes a tendency within the text to drive the unnatural origination of events described. To simplify, the text has as its focus the unnatural elements surrounding the events depicted. This serves as proof for a struggle that can by no means be attributed to natural circumstances but may only be viewed as a theomachy. In other words, the events described are not merely random but witness an orchestration - a struggle between a supernatural entity and an earthly ruler. This strategy is seen in two things: an unnatural death (not by human hand) ascribed to

TABLE 1: Summary of key contributions.

\begin{tabular}{ll}
\hline Scholar & Focus \\
\hline Bickerman & Philological and historical elements \\
Doran & Stylistic devices and the confrontation between Hellenism and Judaism \\
Goldstein & Philological elements, influence and context \\
Schwartz & Dating, authorship and Diasporan influence \\
Van Henten & Noble death and narrative pattern \\
\hline
\end{tabular}

Antiochus and a colourful description of his complete repentance and reversal.

\section{Methodology}

In addressing the questions discussed above, the following aspects will be investigated:

- the main ideas the author aimed to communicate

- the strategies the author applied to move the reader to adopt these ideas

- the elements which form each of these strategies

- the possible impact of each of these elements on the reader and/or hearer.

These aspects may be outlined as follows:

- Ideas: The study will confirm the communication of various important ideas in the text of 2 Maccabees by means of a syntactical and semantic analysis. Although the identification of most of these ideas in itself is not a new contribution to the field, the process of identification is essential in determining the communicative strategy of the author. To study the strategy of the author of moving the reader to adopt certain ideas, the ideas have to be clarified and isolated first. The author chose to provide a description of a specific period in the history of the Jews to elaborate on and incorporate these ideas. Through this, a main theme becomes evident. This, in turn, explains the prominent place given to certain characters and their significance within the narrative plan.

- Strategies: After identifying the ideas and the main theme of the narrative, it is possible to discuss the strategies applied by the author to aim at persuading the reader to adopt them. Such a description of a strategy is closely related to the possible impact on the reader.

\section{Delimitation}

The start of this new pericope is clearly started off with the

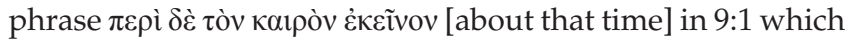
initiates a new scene and setting. A similar phrase marks the

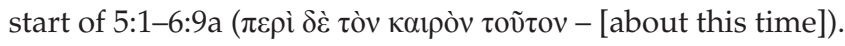
Through this phrase in 9:1, the author links the events of the current pericope with preceding events. The death of Antiochus IV Epiphanes is tied to what just happened in Judea and specifically in Jerusalem. This is evidenced by the mention of the defeats of Nikanor and Timothy's men. The ending of the pericope is as clear as the start. The author jumps to yet another scene in 10:1 with Judas and his companions at the centre, marking 9:29 as the end of the current scene and pericope.

\section{Syntactical and semantic analysis}

The author begins the pericope, which is clearly meant to portray the most negative image of Antiochus IV Epiphanes, with a fitting description of events. In 9:2 Antiochus attempts to rob a temple and secure the city of Persepolis. This reinforces the antagonism of the reader towards the king. Goldstein (1983:349) holds that the name Persepolis is the 
result of a misreading of an original Hebrew source that read 'in Persis, a city'. However, as Doran (2012:186) rightly argues, it seems more likely that the author simply mentioned the most renowned city in Persis in order to highlight the audacity of Antiochus IV. The city Persepolis was the capital of the Achaemenid Empire and was known for the fact that it had been looted and destroyed by Alexander the Great (Diodorus Siculus 17.20-22). It would seem that the author is merely applying a strategy to vilify Antiochus through referring to the temple robbery. Mittag (2006:309-317) provides convincing evidence for such events to have taken place. The fact that needs to be underlined here is that the author has dedicated a section of this pericope to describe both the attempt of plundering the temple and the failure of this mission. In this manner, the author is negatively propagating Antiochus IV as well as achieving to add to his failures this attempted robbery.

The author's aim to utilise the rhetorical possibilities of the downfall of Antiochus IV is seen in the structure of 9:1-29. The rest of the pericope is dedicated to Antiochus IV's afflictions (9:3-10) and the complete reversal of his character and attitude towards the Jews (3:11-29). The misfortune of Antiochus fits his transgressions. This is aligned with the theme of appropriate retribution/just deserts in 2 Maccabees. This retribution is threefold. The king is struck with extreme intestinal pains (9:5), falls off his chariot, sustaining serious injuries (9:7) and worms swarm from his eyes and flesh crumbles off him (9:9). This series of events is introduced by the author's link to what Antiochus did to others: the one who tormented the innards of others (9:6) was now tormented the same way.

Antiochus' self-justification becomes clear through his rage about the events in Judea (9:4). The same use of $\theta 0 \mu$ ó $\varsigma$ ('anger') is found in 4:38; 10:35; and 14:45. Here, the king thinks that he has been wronged by the Jews, as if it were unjust to protect one's own city (Nicklas 2002:83). This attitude of Antiochus, in turn, fits into the theme of the stubborn king. Only at the last moment, after intense punishment, the king changes his opinion and humbles himself before the God of the Jews. Through this, the author maintains suspense throughout this section and ensures the reader's attention, as the battle is not swiftly ended. The fact that God is referred to as $\pi \alpha v \tau \varepsilon \pi$ ó $\pi \tau\rceil \varsigma$ kúpıs [the all-seeing Lord] recalls the confession of Heliodorus in 3:39. The reader is reminded that a challenge against God is futile, as such a battle cannot be won. The reader anticipates the fact that Antiochus will end up the same way as Heliodorus, confessing the might of God.

The verb $\pi \alpha \tau \alpha \dot{\sigma} \sigma \omega \omega$ [strike] in 9:5 demonstrates that what God is doing to Antiochus IV is not merely physical but also spiritual. It is connected with bending the will of man to God's commandments. In LXX Exodus, the verb is abundantly employed (3:20; 7:20, 25; 8:17-17; 9:15, 25; 12:12, 23, 27, 29) where God is forcing the Egyptians to obey his will. In Deuteronomy 28:21, the verb is used to describe what God will do to those who do not obey his commands. In 2 Chronicles 21:18, the verb refers to God chastising the impious king Jehoram. The effect of God's smiting will soon be seen in 9:11-29 where Antiochus is brought to submission and conversion.

Antiochus' last stand against the God of the Jews is eloquently described in 9:7-11. This section starts off with the negation of the verb $\lambda \dot{\eta} \gamma \omega$ [I cease] and ends in 9:11 with the same verb $(\lambda \eta \gamma \omega)$ describing the king ceasing his haughtiness. This rounds off this section and ensures that the reader understands the depth of this final battle: Antiochus' submission does not come easily. He is said to be boiling over/breathing fire ( $\pi \tilde{\nu} \rho \pi v \varepsilon \dot{\varepsilon} \omega v, 9: 7)$. The element of extreme rage adds to the dramatic effect. What is important here is that the author utilises the anger of the king to make his fall more prolific. This verse (9:7) is the only verse listed by

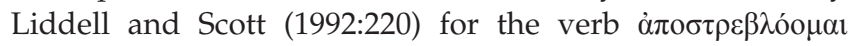
[racked intensely]. The use of this hapax legomenon, together

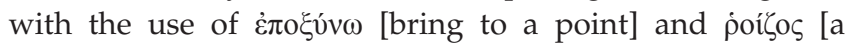
whistling or rushing sound], heightens the dramatic effect (Doran 2012: 188).

The author depicts two contrasting scenes in 9:8-10: one of utter arrogance, and one of utter disgrace. Firstly, the haughtiness of Antiochus IV is described. He opined that he could command the waves of the sea and weigh the mountain heights. This description could either be an allusion to Xerxes (Hdt 7.24, 36-37; Aes, Pers, 744-751, 820) or to God in Isaiah 40:12: 'Who has measured the waters in the hollow of his hand ... and weighed the mountains in scales ... ?' In this regard, Schwartz (2008:357) rightly mentions that 'either allusion would justify the author's assumption that Antiochus' ultimate sin was equating himself with God'.

Secondly, the author provides a graphic description of Antiochus' complete humiliation. He is down on the ground, worms swarm from his eyes, pieces of flesh crumble off him and his stench becomes unbearable (9:8-9). There are many examples for the motif of worms at the death of those who have fought against a god (Hdt 4.205; Paus 9.7.2-3; Jus 16.2; Jos Ant. 17.168-170; Ac 12:23; Luc Alex. 59-60). This mentioning of worms, together with the reference to Antiochus' stench, serves as an effective humiliation of the former persecutor. Doran (2012:189) rightly points out that verse 10 sums up the previous description by its use of

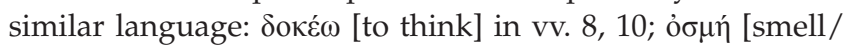

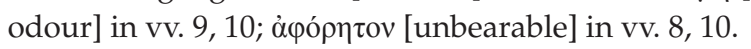

In 9:11-12, the theme is found of the persecutor who is humbled and converted. This theme is also present in the court portrayals of Daniel (3:28-30; 4:25, 34-37; Bel 41) and the Prayer of Nabonidus (4Q242). The cruel tyrant, Antiochus, is forced to his knees by the God of the Jews and confesses that it is not good to be 'godlike' (iఠó $\theta \varepsilon \circ \varsigma$ ) minded (9:12). This scene (9:11-12) is the culmination of various others. Through mentioning the divine whip, the author is referencing the earlier account of Heliodorus $(3: 26,38)$ as well as that of the martyrs $(6: 30 ; 7: 1)$. As mentioned above, the youngest of the seven brothers foretells God's whipping of Antiochus IV in 7:38. 
The polluted one (ó $\mu$ tapós), Antiochus, is finally forced to make a vow to the Master ( vow only comes after a series of 'whippings' by the Lord, who would not now be merciful to him ( $\dot{\varepsilon} \lambda \varepsilon \eta ́ \sigma o v \tau \alpha, 9: 13)$. Through the attributive participle $\tau$ òv ...

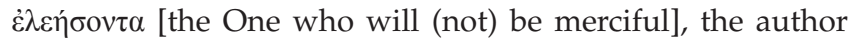
ensures that the reader understands the cause of Antiochus' sudden change of heart. The author will not praise the actions of the tyrant. The vow is driven by God's heavy hand upon the king. The vow progresses unto 9:17 from an impersonal and more logical to more personal and less logical commitments by the king. Firstly, Antiochus makes commitments that are beneficial for the city and the Jews (9:14-15). Secondly, he vows to adorn the temple with votive offerings that he will personally fund (9:16). Lastly, he moves on to the personal undertaking of becoming a Jew and proclaiming the power of God in every region (9:17).

Amongst the benefits for the city is the fact that Antiochus will proclaim the city free $(9: 14)$. This is a weighted promise. Such freedom implied a legal status and commitment on the part of the Hellenistic king (Ma 1999: 150-174) and had a long-lasting effect throughout the Hellenistic period (Gruen 1984:156).

The author sees to it that Antiochus IV restores the honour of the Jews in 9:15. They would have been greatly dishonoured through being left to the wild beasts, being unburied. This dishonour was thoroughly known in antiquity (Sophocles, Antigone; 1 Sm 17:44, 46; Ezk 39:4, 17-20). Now the Jews' honour is restored by being made equal to Athens ("iбovs

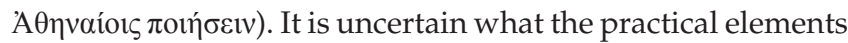
are which cause this restoration of honour. What is certain is the high esteem the city of Athens still had for learning and culture. As mentioned above, the author of 2 Maccabees presents himself as a proper Hellenistic historian and is positive towards the idea of Jews living in a Greek world. This, together with the fact that the text does not provide any negative evaluation of Antiochus' vow, confirms that the author aims, here in 9:15, at restoring the honour of the Jews.

The author gives the reader hope through mentioning that Antiochus IV Epiphanes will supply the money required for

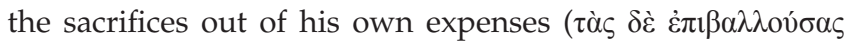

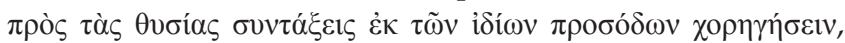
$9: 16)$. The hope is generated by referencing the scene where all was well in Jerusalem and the temple in 3:1-3. The wording, here in 9:16, is identical (leave out 'expenses' ( $\sigma 0 v v \tau \alpha \xi 1 \varsigma)$ ) to that in 3:3 referring to Seleucus. Thus, the reader has hope that, now, peace will return to Jerusalem, as in the time of Onias III.

The most personal and less logical part of Antiochus IV's vow is that he will become a Jew and proclaim the power of God (9:17). Cohen (1999:92-93; 129-130, 151) convincingly argues that this does not imply becoming 'Judaean' but becoming a 'Jew by religion'. This is the most extreme action any of the Jewish enemies has planned. Neither Heliodorus nor Nikanor had planned such things. The extreme nature of this pledge fits this important scene of the complete downfall and conversion of the worst villain of all.

The author uses 9:18 as a bridge to the letter from Antiochus IV to the Jews. There is a sharp contrast between Antiochus' despair in 9:18 and his hope expressed in the letter $(9: 20,22)$. The author uses this tension in exclaiming the permanency of God's judgement upon his opponent. Nothing Antiochus does is able to reverse the path of his demise, not even the declaration of his beneficence towards the Jews in the succeeding letter.

Two aspects regarding the letter in 9:19-27 underpin the humble new status the author gives Antiochus Epiphanes. Firstly, the author explicitly mentions that the letter was in the form of a supplication (9:18). This signifies that the sender has a status inferior to that of the addressee (Welles 1934:57).

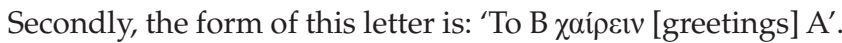
The usual form of royal correspondence in Hellenistic literature is 'A to B zoípewv [greetings]'. Thus, in this letter (9:19-27), the superiority of the receiving party (B), being the Jews, is indicated.

The authenticity of the letter has been widely debated (Doran 2012:191-196; Habicht 1976:5-6; Schwartz 2008:361-362). Domazakis (2018:60) points out the possibility of this letter being a forgery, probably based on a genuine letter of Antiochus IV to the citizens of Antioch or on a Seleucid royal letter. Nisula (2005:217) describes it as a 'stylistic exercise'. For this study, the authenticity would make no difference to the rhetorical value and the author's exploitation/ construction thereof. Yet, the incorporation of the temple in 9:16 seems to show the author of 2 Maccabees' hand in this letter and leans towards Nisula's 'stylistic exercise'. Here, in 9:16, one finds Antiochus' promise that he would decorate the place with the most beautiful gifts. Jordaan (2015:361) places this verse and letter within a larger theme, temple episode 3, namely, the restoration of the Jerusalem temple. Such an appropriation to a larger theme and rhetorical unity further supports the idea of the involvement of the epitomator in this letter. Goldstein (1983:359) has outlined the letter's rhetorical aspects. The author of the letter:

- uses lavish language to gain the sympathy of the readers (9:19-21)

- demonstrates that it is in the reader's best interest to agree to what he proposes $(9: 21 b-25)$

- shows that his actions are not unprecedented $(9: 23,25)$

- reminds the reader of previous benefactions (9:26)

- provides promise of future benefactions (9:27).

The highly rhetorical construction of this letter can either be the product of a separate author of the letter, or the author of 2 Maccabees, who has already been proved to be educated in Hellenistic and rhetorical style.

In this letter, the 'writer' adds to the standard greeting

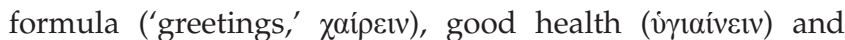
prosperity ( $\varepsilon \tilde{v} \pi \rho \alpha ́ \tau \tau \varepsilon เ v)$. The usual greeting in royal 
correspondence entails only the first of these three elements. There is no other example for the use of three infinitives being used in a greeting formula in Greek correspondence (Doran 2012:192). The use of these infinitives implies a friendly tone, rather than formal. This fits into the author's strategy to present Antiochus IV as a newly repented man, who thinks less of himself than before and who tries his best to make amends with the Jews.

The phrase in 9:20 directly after the greeting formula $\varepsilon i$ ๕̌ $\rho \omega \sigma \theta \varepsilon$ [if you are well] is standard style (Ant 12.148; Exler 1923:103-107). The combination of best wishes for children and for private affairs, however, points to informal correspondence (Doran 2012:193). A fact which further supports this informality is the mention of the king's health, which is not expected in a formal letter concerning succession (Doran 2012:194). Through the form and content of this letter, the author stresses the personal tone.

The fact that Antiochus prays to God and places his hope in heaven is ironic but proof of his promise to become a Jew. Yet, as the author made clear $(9: 13,18)$, there is no chance for Epiphanes to escape the judgement of God. This is also evident through the harsh manner in which Antiochus' death is summarised in 9:28. As in 2:21; 3:20, 34; 7:11; 8:20; 9:4; and $15: 8$, the term 'heaven' is used metonymically for 'God'.

The letter demonstrates a euphemistic description of the

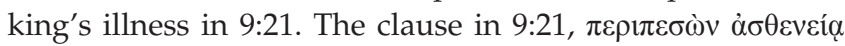

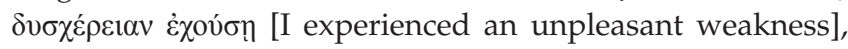
underplays the severity of the king's situation, which is so severe that he now makes plans for succession. It is unclear whether the author wants to use this as a negative depiction of the king, or whether the king regards it as a precaution to avoid panic. Nevertheless, in both cases, tension is maintained between the words of the letter and the king's fate (already fixed by God). The same is true of the king's hope to escape the weakness (9:22). The reader knows the doomed fate of Antiochus through both Eleazar's (6:26) and the seventh brother's prediction (7:35).

In 9:23-27, Antiochus proclaims his son, Antiochus V, as his successor. Antiochus III indeed proclaimed his son Antiochus IV, and later on his son Seleucus, as successor during his campaigns to reassert Seleucid authority in the eastern part of his empire (Ma 1999: 63-65; Parker \& Dubberstein 1956:22). Again in 9:24, as in 9:21, a softer expression is used to describe the possible death of the king: 'if something unexpected

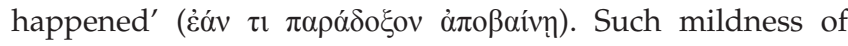
description is also found in the testament of Ptolemy VIII: 'if something of what happens to humans should happen' ('̇óv

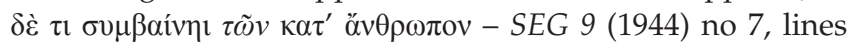
11-12), as well as in Herod's arrangements of his successor (Jos Ant. 15.184). With this in mind, it would seem that the euphemism in 9:21 is not an attempt by the author to depict Antiochus in a negative manner, but rather royal formality.

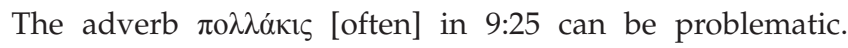
Epiphanes could not have traversed the upper satrapies often, as he only made one expedition there. Schwartz (2008:364) aims at solving this historical fault through stating that the author jokes with Antiochus IV through depicting him as exaggerating the truth. Goldstein (1983:532) suggested

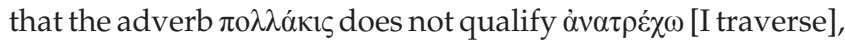

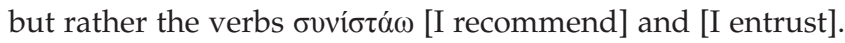
Accordingly, Goldstein takes the two last-mentioned verbs as in the epistolary imperfect. Doran (2012:195) convincingly argues against Goldstein on the grounds that the epistolary imperfect is very rare and that the adverb qualifies the participle that immediately follows. It would seem that Schwartz's (2008:364) argument regarding the mockery of Antiochus would be most logical in this instance.

The writer of the letter speaks of the past and possible future benefactions and how it is linked to the community's submission to the king. The author explicates the irony through the fact that the Jews experienced the complete opposite of beneficence and would not want Antiochus V to follow the same policy as his father. The irony is further communicated through the sharp contrast between the last line of the letter, which describes the benevolent attributes of the king, and the harsh description in 9:28, which moves to a cold and negative description of his death.

\section{Ideas}

Understanding the theomachy presented in 2 Maccabees 9 has as its prerequisite an understanding of the place of the Jerusalem temple. It is this human challenger Antiochus IV who upset the balance through desecrating the temple (5:1516), a temple which represents the stability of the providence of the God of the Jews. It is important for the author to place Antiochus IV directly opposite God in this last battle. The struggle is between the one who had dared to enter God's holy temple and touched the vessels in the Jerusalem temple and the God who protects that place; between the king who regards himself as superhuman $(5: 21 ; 9: 8)$ and the powerful, all-seeing God of the Jews.

Here, in 2 Maccabees 9, the reader and/or hearer needs to be convinced of the heavenly origin of the events depicted for one reason - to prove that these circumstances are not a random chain of events. Such a randomness would nullify the rhetorical effect of a purposed end to Antiochus' life as well as disconnect the characters within the text from their initial binding to a greater scheme of things. If the God of the Jews brought the wrath on his people in times of his anger, and brings victory in times of his mercy, then this is a time of mercy and God is very actively dealing with the perpetrators. Appropriate retribution is at hand.

\section{Communicative strategy and its elements}

Earlier in the narrative, in 2 Maccabees 3:38-39 and 2 Maccabees 7:35-36, the enemies of God had been warned. This warning also served the purpose of guiding the reader and/or hearer not to oppose the God of the Jews. Now, in this 
pericope, proof is given of the result of such opposition. It stands in sharp contrast with the oppression over the Jews in the martyrologies of 2 Maccabees 6-7. Here, the death of the oppressor is linked with the martyrs in two ways. Firstly, the description of the martyrs' death is the pivotal point in the narrative whereafter the Jews are victorious. Now God, who is the ally of the Jews, will add the punishment of Antiochus IV Epiphanes to the victories he has given them. Secondly, this description is linked to the martyrdoms through the fulfilment of the prophetic utterance of the seventh brother that the tormentors of the Jews, especially Antiochus, will not escape judgement (7:35-37).

It is imperative that the author portrays this final conflict as a direct battle between the king and God. The outcome has already been established. This is why the king does not get any credit for his repentance and conversion. It is not a chance to escape judgement. It is merely the God of the Jews forcing the king to kneel before he receives his penalty. He has to suffer a terrible death and, to make it clear that God is in control, Antiochus has to die in a manner similar to what he has done to others.

Three main strategies are applied: firstly, the text utilises suspense and relief in 9:1 onwards. The reader is told that Antiochus IV is on his way back (9:1). By now, the reader waits in suspense, as he and/or she is well aware of the possible meaning of the return of the cruel tyrant. Antiochus will certainly aim to avenge what has happened to Nikanor and the followers of Timothy. This suspense is relieved briefly by the notion that Antiochus made his way shamefaced because he was put to flight by the inhabitants of Persepolis (9:2). Yet, the suspense is regained through the communication of the tyrant's plans to destroy Jerusalem (9:4). Finally, the reader is greatly relieved by the description of Antiochus' last moments, his appropriate retribution and his last wishes for the good of the Jews (9:5-28).

Secondly, through setting up a battle between man and God, the author warns the reader not to fight against God. This happens by means of an emotional appeal through communicating punishment and reward. The reader is moved to fear the possible outcome of opposing God in any way.

In this manner, the reader is aided to adopt the ideas within the text by means of emotional involvement, warning by means of an emotional appeal and proof of divine origination. All events are supernaturally driven.

\section{Possible impact}

The author aims at moving the reader from an attitude of doubt and distrust in the God of the Jews because of the bad things that happened, to an attitude of trust and obedience in the God who is just and powerful. The danger exists that the reader lost hope in the God of the Jews, as the villains in 2 Maccabees were not prevented in executing their evil plans. Up until now, it seemed that Antiochus IV went unpunished for his cruelty against the Jews and that God has therefore either abandoned the Jews or is not able to stop the enemies of the Jews.

The battle between man and God provides a scene which is ideal for keeping the reader interested and maintaining tension. This scene also creates a scenario where the reader has to choose a side. The author makes this choice easier through presenting God as good and strong and Antiochus as bad and weak; God as the victor and Antiochus as the defeated. The reader is aided to choose the all-powerful, omnipotent and just God of the Jews and to choose against Antiochus, the temple robber, the unwise, the shameful and the one who is full of hatred towards the Jews.

Finally, the text ensures the reader's discovery that God personally seeks out those who fight against him and deals directly with them. This divine origination moves the reader to both compliance and pride in the Jewish cause and their Divine Warrior.

\section{Conclusion}

This analysis of 2 Maccabees 9 explicates a highly aimed rhetorical strategy. This is shown through the vivid description of the death of Antiochus IV and in sharp contrast between the ending of the letter and the text that immediately follows. Furthermore, the construction and incorporation of the letter within 2 Maccabees 9 and its finely tuned content bears witness to an overarching strategy to move the reader and/or hearer to adopt the view that the God of the Jews protects the Jerusalem temple, deals swiftly with the sins of the Jews and personally avenges his people.

The text overemphasises the supernatural. This connects the events recounted with the idea that the God of the Jews is in complete control and actually drives the events, dealing swiftly with the enemies of his people. The text shows the God of the Jews directly causing the various inflictions upon his adversary Antiochus. The theme of divine retribution that is introduced earlier in 2 Maccabees, especially through the words of the martyr in 2 Maccabees 7:35-36 is not only continued but elaborated and proven in 2 Maccabees 9. The God of the Jews has to be portrayed as the dealer of both mercy and wrath. Here, in 2 Maccabees 9, he deals his mercy through the enactment of appropriate retribution: Antiochus dies in a manner similar to what he has done to others. The text has to demonstrate that events are not random but supernaturally driven. Without this supernatural element, there would be no theomachy and no divine interruption and involvement. Therefore, the text was shown to emphasise the supernatural in order to explicate the involvement of the God of the Jews. The reader/hearer is guided to view the circumstances depicted not as random but orchestrated and driven. In order to bind these themes, ideas and evidence together, the text was shown to apply three rhetorical strategies, namely, suspense and relief, an emotional appeal (punishment and reward) and a logical appeal. These strategies ensure the reader/hearer's attention and adoption of key concepts such as the personal involvement of the God 
of the Jews, the divine appropriation and significance of events and the importance of the temple and its sanctity.

The text of 2 Maccabees 9 is an exemplary sample of the highly rhetorical nature and carefully constructed narrative aim of the text of 2 Maccabees. Through this investigation into the combined significance of syntactical and semantic elements, pragmatic aspects and the relation between an overemphasis on the supernatural and sensitive ideas has been demonstrated. Consequently, the study has shown how the text of 2 Maccabees 9 forms part of a narrative where drastic measures are taken to deal with innovative ideas that aim to conceptualise dubious events in the history of the Jews.

\section{Acknowledgements Competing interests}

The author declares that he has no financial or personal relationships which may have inappropriately influenced him in writing this article.

\section{References}

Bickerman, E.J., 1979, The god of the Maccabees: Studies in the meaning and origin of the Maccabean revolt, Brill, Leiden. [Studies in Judaism in Late Antiquity 32].
Cohen, S.J.D., 1999, The beginnings of Jewishness: Boundaries, varietys, uncertainties, University of California Press, Berkeley, CA. [HCS 31].

Domazakis, N., 2018, The neologisms in 2 Maccabees, Lund University (Media Tryck), Lund.

Doran, R., 2012, 2 Maccabees: A critical commentary, Fortress Press, Minneapolis, MN.

Exler, F.X.J., 1923, The form of the ancient Greek letter of the epistolary papyri (3rd c.B.C. - 3rd c.A.D.): A study in Greek epistolography, Catholic University of America Press, Washington, DC.

Goldstein, J.A., 1983, II Maccabees. AB 41A, Doubleday, Garden City, New York.

Gruen, E.S., 1984, The hellenistic world and the coming of Rome (2 vols.), University of California Press, Berkeley, CA.

Habicht, C., 1976, 2. Makkabäerbuch, Mohn, Gütersloh, [JSHRZ I, 3].

Jordaan, P.J., 2015, 'The temple in 2 Maccabees: Dynamics and episodes', Japanese Society for Experimental Mechanics 24(1), 352-365.

Liddell, H.G. \& Scott, R., (compilers), 1992, A Greek English lexicon, Clarendon, Oxford. [repr. of rev. 9th ed. by H. S. Jones et al.].

Ma, J., 1999, Antiochus III and the cities of Western Asia minor, Oxford University Press, Oxford.

Mittag, P. F., 2006, Antiochus IV epiphanes: Eine politische biographie, Akadamie, Berlin.

Nicklas, T., 2002, 'Der Historiker als Erzäler: Zur Zeichnung des Seleukidenkönigs Antiochus in 2 Makk. IX', VT (52), 80-92.

Nisula, T., 2005, “'Time has passed since you sent your letter”: Letter phraseology in 1 and 2 Maccabees', JSP 14(3), 201-222. https://doi.org/10.1177/0951820705053848

Parker, R.A. \& Dubberstein, W.H., 1956, Babylonian chronology 626 B.C. - A.D. 75, Brown University Press, Providence, R.I. [Brown University Studies 19].

Schwartz, D.R., 2008, 2 Maccabees, Walter de Gruyter, Berlin.

Van Henten, J.W., 1997, The Maccabean martyrs as saviours of the Jewish people: A study of 2 and 4 Maccabees, Brill, Leiden.

Welles, C.B., 1934, Royal correspondence in the Hellenistic period: A study in Greek epigraphy, Yale University Press, New Haven, CT. 